\title{
HOW SOCIAL MEDIA AFFECT YOUTH CIVIC PARTICIPATION IN CHINA
}

\author{
Jie Jiang ${ }^{1}$, Algimants Kontauts ${ }^{2}$ \\ University of Latvia (Latvia), Pricewaterhouse Coopers (Latvia)
}

\begin{abstract}
This study is focused on social media in China and its influence on youth civic participation. In China, a trend of increasing usage of social media platforms has been observed, in particularly WeChat, Weibo, QQ, Douyin, and Meitu. The aim of this research is to explore the link between the use of these social media platforms and civic participation among the youth in China, specifically, whether social media platforms have positive effect on encouragement of youth civic participation. The use of social media platforms is measured by the number of social media accounts, the duration of usage of these accounts, and the average time spending on social media accounts weekly, while civic participation through social media is to measure both civic participation activities and its link with the social media usage.

KEYWORDS: social media, WeChat, youth, civic participation, China.
\end{abstract}

JEL CODES: J68, L86.

DOI:

\section{Introduction}

There is an increasing recognition of the importance of youth civic engagement, particularly in China and other countries in the Pacific due to its potential to promote more democratic forms of engagement between citizens and state ${ }^{3}$. This research has been conducted to explore the link between the use of social media platforms and civic participation among the youth in China. The hypothesis of this research is that there is statically significant percentage of youth with social media; and the usage of social media has positive effect on promoting civic activities in China. To test these hypotheses, literature review and statistic data analysis have been used to analyse the situation of China's youth civic participation, civic engagement and social media, as well as the current usage of social media in China. A survey has been conducted to understand the effects of social media usage in promoting civic participation among Chinese youth, such media potentials and possible negative factors. A snowball sampling method has been adopted and 301 valid responses have been received. The result reveals that the usage of social media has a moderate positive effect on promotion of civic participation.

1 Jie Jiang - University of Latvia, Faculty of Business, Management and Economics, Field of Economics

Scientific interests: international business, global marketing, and data analysis

E-mail: Jessica.j.1229@gmail.com

Tel. +37124336107.

2 Algimants Kontauts - PricewaterhouseCoopers, Assurance Department, Field of Audit

Scientific interests: International relations, financial instruments analysis, national branding

E-mail: Algimkontas@yahoo.com

3 UNICEF Research report: Young People's Civic Engagement in East Asia and the Pacific. Retrieved from https://www.unicef. org/adolescence/cypguide/files/EAPRO_study_by_Innovations_in_Civic_Participation.pdf 


\section{Situation of youth civic participation in China}

China has been through a rapid development in the past 40 years since the implantation of its open-door policy $^{4}$ which leads to remarkable impacts in various social aspects. The import of western ideology such as democracy, liberalism, justice, capitalism, science and belief in diversity of social values has reshaped the population and the whole youth generation (Ngai et al., 2011). This trend leads to pressure for the ruling party not only on how to confront with the changes in its social and demographic transformation, but also on how to create appropriate solutions to educate its youth, the future force of the country, to positively response to its coming social and environmental problems, and to actively participate in civic activities.

Traditionally, the main option for youth civic participation in China is to join the Chinese Communist

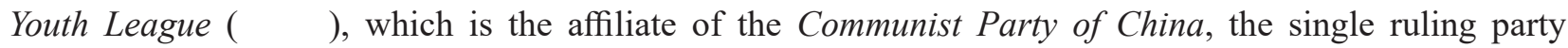
of China (Yang et al., 2016). As a semi-official youth work organization which is organized on the Chinese Communist party pattern, the major purpose of the youth league is to align youth policy with its communist ideology to become a strong supporter of the country's ideology and a qualified citizen (Johnson et al., 2017). On the one hand, the Youth League indeed contribute to provide the youth an increased access to information and more opportunities to participate in civic activities such as community based learning activities (for example hobby classes, free sport fields, and working skills trainings), volunteering activities, and community based research activities (such as community survey centre and free library), on the other hand, its semigovernmental role and agenda creates barriers for members to have different voices and fully perform their roles as citizens, such as having political opinions and suggestions on the diversity building.

Against this background, searching for a more open source that is more accessible, economical, and efficient to encourage the youth civic rights awareness and civic participation is in local and international researchers' agenda. L. Johnson and his team (2007) described a unique, service-learning approach to youth development, the Jane Goodall Institute's Roots \& Shoots program, and explored perceptions of the program impact on the personal and social development of Chinese youth. L. Ke and H. Starkey (2014) explored how Chinese university students use intranet to participate in civic activities. C. Yuen (2013) performed research on the relationship between school and civic engagement. D. Yang (2016) examined the use of microblogs to promote civic participation among Chinese undergraduate and graduate students. And Y. Yin (2017) explored how Bilibili, a youth open platform and video site in China, with a bullet-commenting technology can help in boosting participation culture.

\section{Civic engagement and social media}

Social media has been praised for its potential in facilitating civic engagement. Many researches have performed research regarding the links between social media and public issues/political topics. It has been associated with the empowering of the youth (Thackeray 2010), building citizen trusts (Warren, 2014), online political expressing (Yamamoto, 2013), and civic learning (Bennett, 2009). Relevant empirical studies showed positive use of social media to boost transparency (Pryor et al., 2014; Bonson et al., 2012). Z. Zhong (2014) has investigated how social networking usages and social capital elicit impact on civic engagement, and the results show that online bonding and bridging social capital are positively related to online civic involvement. N. Liem (2009) concluded that social media platforms, as emerging promoting spaces, have paved the way for the re-conceptualization of political engagement, especially among the youth. J. Uldam and A. Vestergaard (2015) empirically explored how different practices of public participation are played out in social media, focusing particularly on political participation. S. Okazaki and C. Taylor (2013) found that three key theoretical perspectives (networking capability, image transferability, and personal extensibility) provide strong potential for better understanding the advantages and disadvantages of social media use for

4 The open door policy, officially called 'Open and Reform', was proposed in December of 1978 by Chinese then leader Deng Xiaoping. Under the open-door policy, foreigners and foreign entities are encouraged to enter China and Chinese people are encouraged to go abroad, for business, education, and tourism. 
promotors. The study by S. Masiha and his colleagues (2018) explored the significant correlation between the sharing political views on Facebook in different ways and their role in motivating the youth for political participation, and suggested that "organization related to information technology such as institutes of information technology and ministry of information technology need to introduce social media platform like Facebook for freedom of expression for social and particularly political problems in the society."

However, there are also some researches who show that the connection between social media and civic activities promotion is not always positive. After examining the impact of both media tools and participant inclusion in organizational efficacy and controlling for various organizational characteristics, S. Gaby (2017) concluded that using media tools is not sufficient to increase efficacy since the way they are used also matters and suggests that inclusion of the youth in daily decision making processes, however, increases organizational efficacy and the relationship is robust by the inclusion of organizational characteristics.

\section{Current situation of social media usage in China}

According to China Internet Network Information Centre (CNNIC), the aggregate number of active internet users in China reached 500 million users in 2018, representing $57.7 \%$ of the total population ${ }^{5}$. Thus, China is home to some of the world's largest social and messaging networks, with combined more than one billion users for the top five social media platforms ${ }^{6}$, namely WeChat, Weibo, QQ, Douyin, and Meipian . According to the data from Statista, there are more than 69 percent of Chinese people aged from 15 to 19 years who were social media users in 2017, and the aggregate number of social network users in China is estimated to reach 725 million in $2022^{8}$. In theory, social media could be an excellent channel to promote youth civic participation, and based on this hypothesis is conducted this research.

\section{The survey}

The authors adopted a snowball sampling method to collect data for this survey. In contrast to probability sampling, which is based on random selection and each element is given an equal chance to be selected, snowball sampling is not totally random. Individuals are invited and they are used to locate others in their network and who in turn identify others (Dudovskiy, 2016). In general, it is applied when it is difficult to identify respondents and they are best located through referral networks. It was chosen for this research because it meets the objective, i.e., the relevance of the usage of social media and youth civic participation, with a clear target group - Chinese young people within the age gap of 15 to 24 years ${ }^{9}$ who have access to social media. Other reasons for choosing snowball sampling were the cost and time efficiency.

The target group of this survey is Chinese citizens of the age group from 15 to 24 years old. The questionnaire was made in Chinese and English to minimize the ambiguity between the language of the survey recipients (Chinese) and the language of this report (English). There are two main sections in the questionnaire: the usage of social media and the civic participation through social media. The usage of social media platforms is measured by the number of social media accounts, the duration of usage of these accounts, and the average time spending on social media accounts weekly. And the civic participation through social media is to measure both civic participation activities and its link with the social media usage.

\footnotetext{
Source of data: China Internet Network Information Center (2018). Retrieved from https://cnnic.com.cn/

6 For statistic purpose, a user who has accounts in 2 different social media is assumed as "two" social media accounts in this data calculation.

7 Source of data: Digital in 2017: Global overview (2018). Retrieved from https://wearesocial.com/special-reports/digital-in2017-global-overview

8 Source of data: China Internet Network Information Center (2018). Retrieved from https://cnnic.com.cn/

9 According to the UN, that youth is "as those persons between the ages of 15 and 24 years, without prejudice to other definitions by Member States".
} 


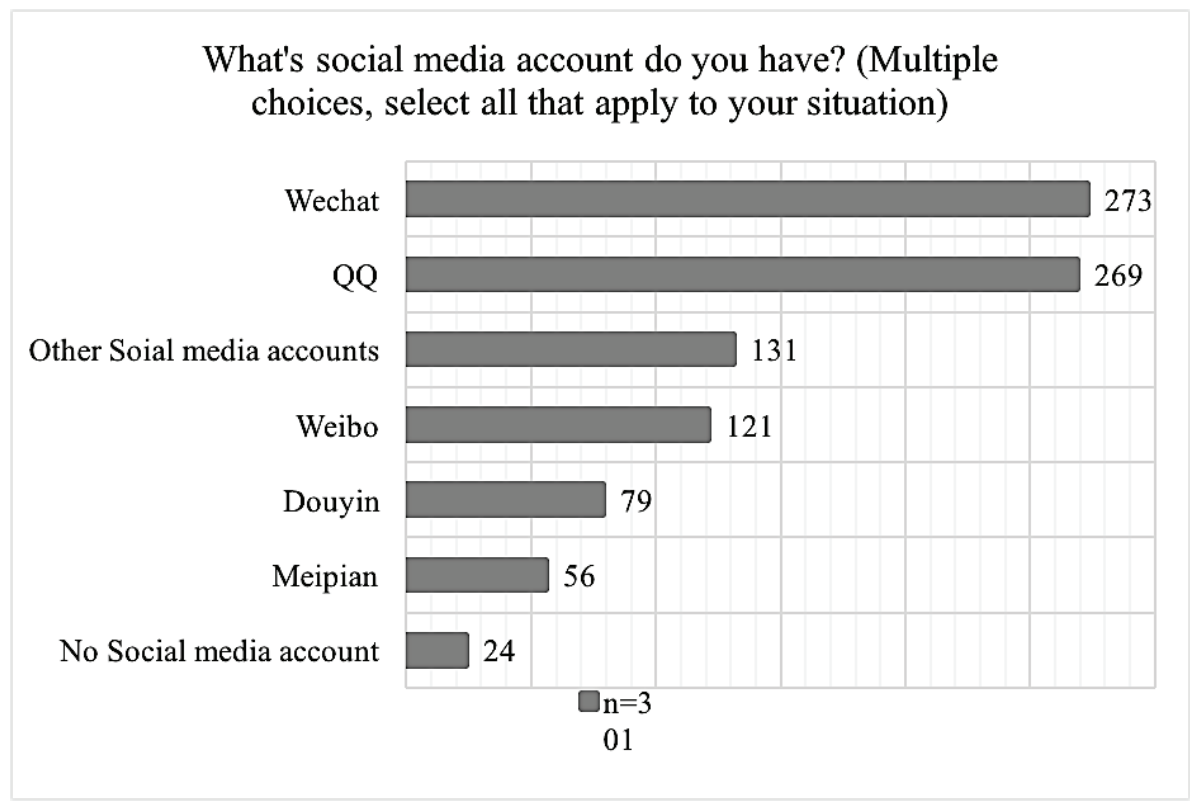

Fig. 1. Survey results on the social media account usage among the 15-24 years old Chinese in 2018

Source: constructed by the authors based on the survey results.

The survey was performed during the period of October $26^{\text {th }}$ (Monday) till November $5^{\text {th }}$ (Monday), and in total 308 instances of feedback has been received with 301 valid responses. The data meets the minimum number of valid responses necessary in the initial research design ( $>=300$ valid number of responses).

From the 301 valid responses, 277 people have chosen that he/she has at least one social media account, which leads to $92.03 \%$ of the coverage among the survey participants. Also, as the survey revealed, most of the recipients have multiple social media account, as shown in Figure 1, what means that in average 3.35 social media platforms are used per social media user, and the top used social media platforms are WeChat and $Q Q$, respectively $98.5 \%$ and $97.1 \%$ of the social media users that have accounts there.

As can be seen in Figure 2, the majority, covering 58.8\% of the survey participants, have been using social media accounts for more than five years. A possible reason of this situation is that Chinese customers start using social media very early; according to Internal Statistics of Tencent $2017^{10}$, the average age of the user of WeChat in China is only 26 years.

For the number of friends per media account, as shown in Figure 3, most of the survey participants have between 50 and 150 friends in their friends list, respectively $40.07 \%$ and $28.88 \%$ of all the social media users. Also, from the survey, it shows that the average hours spent on social media weekly is 7.7 hours, with standard deviation of 0.33 hours. Data gathered from this section indicates social media platforms, especially the top 5 platforms, which are widely and regularly used, and it can be assumed to be statistically efficient platforms to work on to increase the information flow.

The next section of the questionnaire is about the civic participation among the survey participants. Figure 4 shows that only 113 of 301 survey participants have experience in civic activities and mostly in volunteering activities hosted by the local schools and service learning/community based learning activities hosted by the Youth League, respectively $33.5 \%$ and $12.3 \%$ of the total participants. And the top reason chosen for not participating is the lack of information available about these activities. This suggests that more efforts should be put in the event promotion and the free flow of information, which are in demand.

10 Source of data: Tencent Annual Report 2017 (in Chinese). Retrieved from http://www.tencent.com/zh-cn/articles/17000391523362601.pdf 


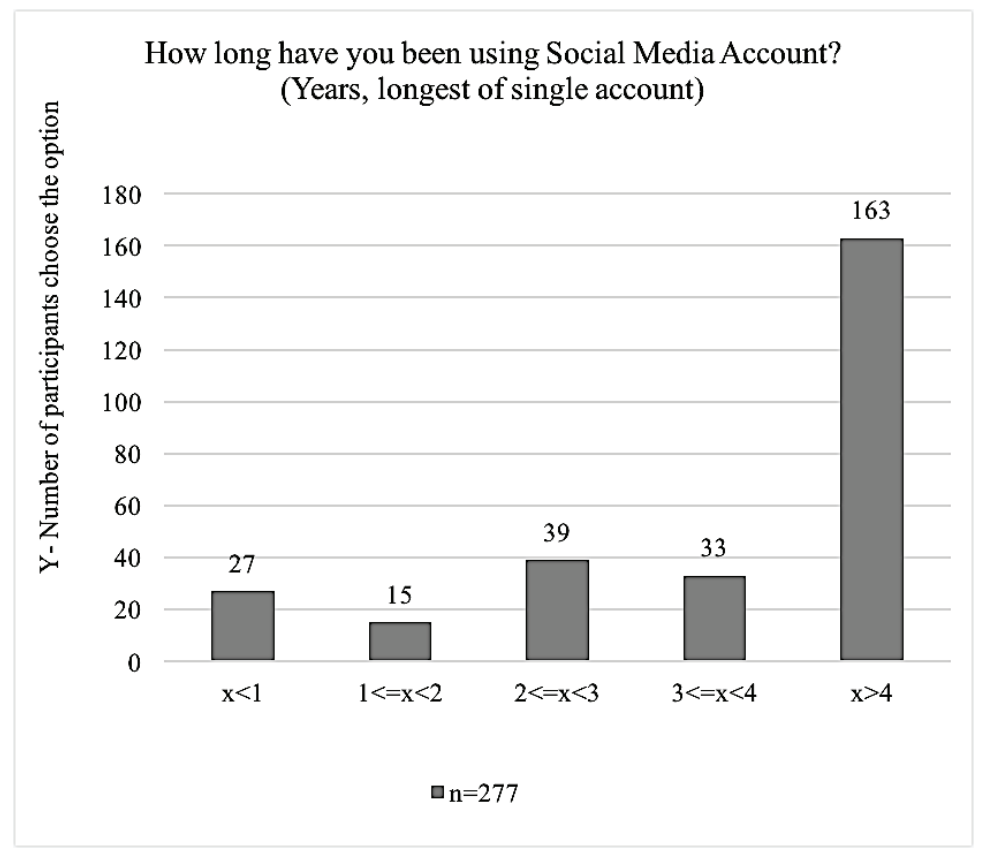

Fig. 2. Duration of the social media usage among the 15-24 years old Chinese in 2018

Source: constructed by the authors based on the survey results.

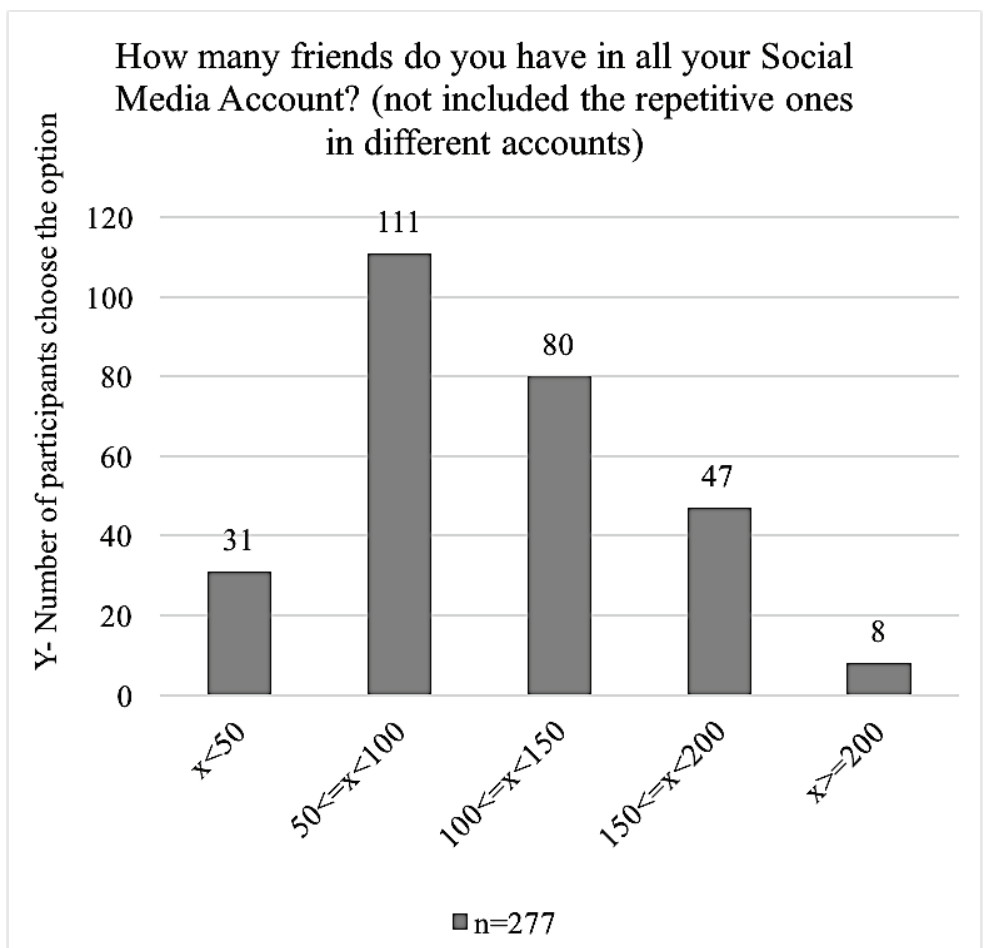

Fig. 3. Survey results on the number of friends on social media friend list among the 15-24 years old Chinese in 2018 Source: constructed by the authors based on the survey results. 


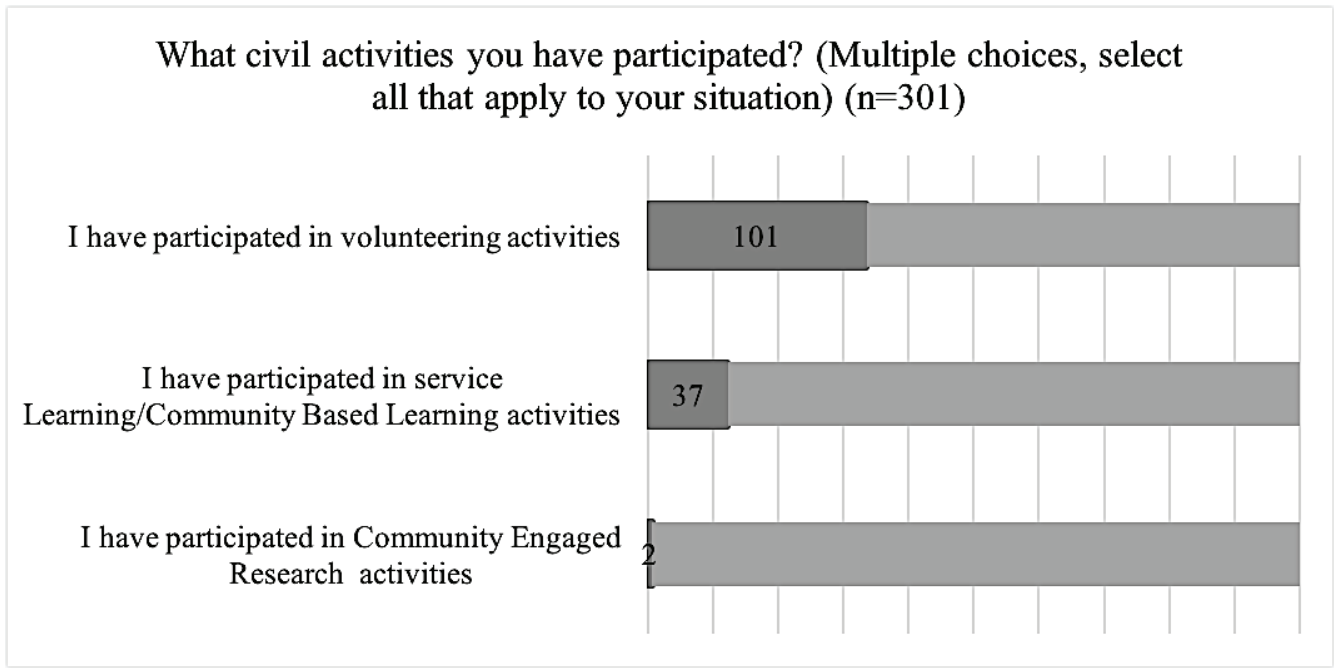

Fig. 4. Survey results on the duration of the social media usage among the 15-24 years old Chinese in 2018 Source: constructed by the authors based on the survey results.

\section{Social Media and its positive effects in encouraging youth civic participation (Multiple choices, select all that apply to your situation) $(\mathrm{n}=277)$}

I discuss various public issues in online social groups I post pictures about public issues on my profile page I post video clip about public issues on my profile page I post text about public issues on my profile page I share information of youth events on my timeline I invite people online on different civic activities

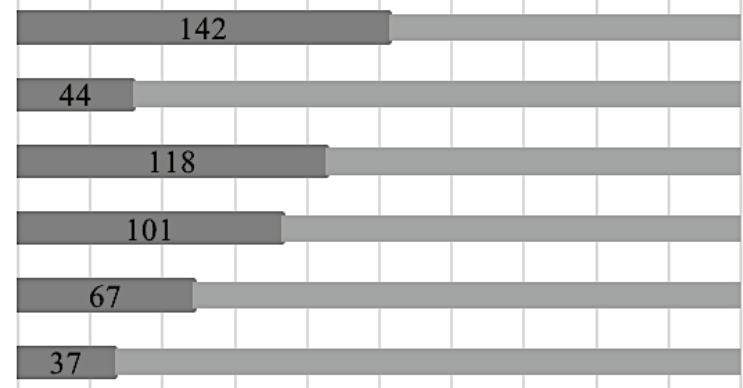

Fig. 5. Survey results on social media and its positive effect in encouraging youth civic participation among the 15-24 years old Chinese in 2018

Source: constructed by the authors based on the survey results.

The next section of the questionnaire revealed that survey participants are using social media to share information about civic participation. As shown in Figure 5, more than half (51.3\%) of the survey participants have been involved in online discussions within online social group with $42.6 \%$ of the survey participants sharing video contents regarding public issues on their profile page (note: Qzone in $Q Q$ and Moment in WeChat). Respectively $36.5 \%, 15.9 \%, 24.2 \%$ of participants have shared text or visual content about public issues or information about youth events on their profile page. This initiative of involving in public-related issues in discussions and sharing of relevant information suggests that the social media platform is acting as an effective tool for young people to express their opinions and contribute to the promotion of organized civic events. Moreover, $13.4 \%$ of the participants take a step further inviting people online to different civic activities, either inviting their peers/friends to those events or using it as a promoting tool by the organizers, in both ways the youth civic event promotion benefits from it. 
On the other hand, the survey also revealed some negative effects of social media to civic participation promotion. As Figure 6 demonstrates, a big percentage of people (42.2\%) do confirm that some comments in social media regarding public issues are deliberately offensive or of provocative content, and a noticeable amount of people (8.7\%) do not feel comfortable when are targeted in civic activities promotions via social media. These findings show that people do have concerns about promotions of civic participation through social media, and most concerns are connected to the regulation in a green social media environment and private data protection.

\section{Social Media and its negative effects in encouraging youth civic participation (Multiple choices, select all that apply to your situation) $(\mathrm{n}=277)$}

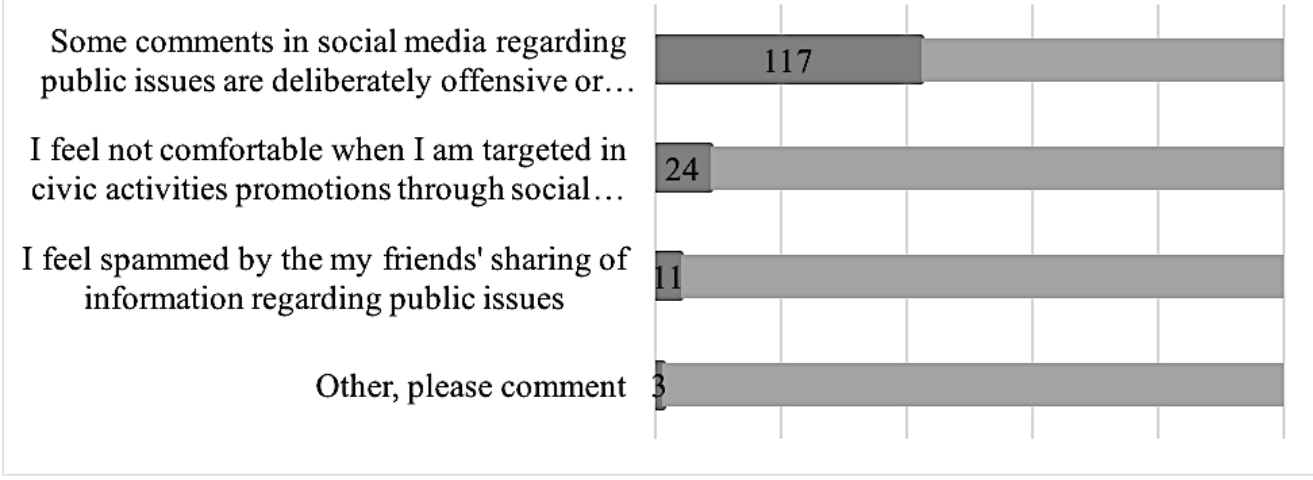

Fig. 6. Survey results on social media and its negative effect in encouraging youth civic participation among the 15-24 years old Chinese in 2018

Source: constructed by the authors based on the survey results.

To conclude, the survey results match the hypothesis that social media has positive relation with youth civic participation, and it contributes to the provision of platforms that discuss public affairs and spread the information about participation of civic activities in the youth community. Furthermore, at the same time, more regulations are in demand to keep a green internet environment and data protection.

\section{Conclusions}

Due to the culture and historical reason, civic participation among the Chinese youth still is a rather new topic. People lack motivation and information regarding their civic rights and participation in civic activities. Therefore, more research should be conducted on promotion of youth civic participation using effective ways. In theory, social media is a way with no entrance limit, widely used, and a low-cost way in promoting information. This survey confirms the assumption that participants do use social media to share information about public affairs and participation in civic activities, with understandable concern about the green internet environment and protection of secured data.

This work is more devoted to quantitative research based on the survey of the Chinese youth. For the future research, more studies should be done analysing the Chinese youth policy, the promotion of nongovernment youth organizations, as well as the culture and psychological factors that affect the youth civic participation in China.

\section{References}

Bennett, W. L., Wells, C., Rank, A. (2009). Young Citizens and Civic Learning: Two Paradigms of Citizenship in the Digital Age. Citizenship Studies, Vol. 13, No. 2, pp. 105-120. 
Bonsón, E., Torres, L., Royo, S., Flores, F. (2012). Local e-Government 2.0: Social Media and Corporate Transparency in Municipalities. Government Information Quarterly, Vol. 29, No. 2, pp. 123-132.

Dudovskiy, J. (2016). The Ultimate Guide to Writing a Dissertation in Business Studies: A Step-by-Step Assistance. Available at: https://research-methodology.net/sampling-in-primary-data-collection/snowball-sampling/

Gaby, S. (2017). Media Use and Participant Inclusion: Influences on Efficacy in Paid Staff Youth Nonprofit Civic Organizations. Social Movements and Media, Vol. 14, pp. 209-240.

Johnson, L., Johnson-Pynn, J., Pynn, T. (2007). Youth Civic Engagement in China: Results from a Program Promotion Environmental Activism. Journal of Adolescent Research, Vol. 22, No. 4, pp. 355-386.

Ke, L., Starkey, H. (2014). Active Citizens, Good Citizens, and Insouciant Bystanders: The Educational Implications of Chinese University Students' Civic Participation via Social Networking. London Review of Education, Vol. 12, No. 1, pp. 50-62.

Lim, N. (2009). Novel or Novice: Exploring the Contextual Realities of Youth Political Participation in the Age of Social Media. Philippine Sociological Review, Vol. 57, pp. 61-78.

Masiha, S., Habiba, U., Abbas, Z., Saud, M., Ariadi, S. (2018). Exploring the Link between the Use of Facebook and Political Participation among Youth in Pakistan. Journal of Political Sciences \& Public Affairs, Vol. 6, No. 1, pp. 1-7.

Ngai,N., Ngai, S., Wei, F. (2011). Revisiting China's Youth Policy. Forum paper. Available at: http://www.youthpolicy. org/national/China_2011_Youth_Policy_Situation_Article.pdf

Okazaki, S., Taylor, C. (2013). Social Media and International Advertising: Theoretical Challenges and Future Directions. International Marketing Review, Vol. 30, No. 1, pp. 56-71.

Pryor, M. G., Wulf, M., Alanazi, W., Alhamad, N., Shomefun, O. (2014). The Role of Social Media in Transforming Governments and Nations. International Journal of Business and Public Administration, Vol. 11, No. 1, pp. 19-30.

Thackeray, R., Hunter, M. (2010). Empowering Youth: Use of Technology in Advocacy to Affect Social Change. Journal of Computer-Mediated Communication, Vol. 15, No. 4, pp. 575-591.

Uldam, J., Vestergaard, A. (2015). Introduction: Social Media and Civic Engagement. Palgrave Macmillan.

Warren, A. M., Sulaiman, A., Jaafar, N. I. (2014). Social Media Effects on Fostering Online Civic Engagement and Building Citizen Trust and Trust in Institutions. Government Information Quarterly, Vol. 31, No. 2, pp. $291-301$.

Yamamoto, M., Kushin, M. J., Dalisay, F. (2013). Social Media and Mobiles as Political Mobilization Forces for Young Adults: Examining the Moderating Role of Online Political Expression in Political Participation. New Media \& Society, Vol. 17, No. 6, pp. 880-898.

Yang, B., He, Y., Long, W. (2016). Alienation of Civic Engagement in China? Case Studies on Social Governance in Hangzhou. Voluntas, Vol. 27, pp. 2150-2172.

Yang, D. (2016). Microblogs and Civic Participation among Chinese Undergraduate and Graduate Students. Master thesis. Available at: https://wakespace.lib.wfu.edu/bitstream/handle/10339/59326/Yang_wfu_0248M_10916.pdf

Yin, Y., Fung, A. (2017). Youth Online Cultural Participation and Bilibili: An Alternative Form of Democracy in China? Digital Media Integration for Participatory Democracy, Vol. 3, pp. 130-154.

Yuen, C. (2013). School Engagement and Civic Engagement as Predictors for the Future Political Participation of Ethnic Chinese and South Asian Adolescents in Hong Kong. Migracijske i etničke teme, Vol. 29, No. 3, pp. $317-342$.

Zhong, Z. (2014). Civic Engagement among Educated Chinese Youth: The Role of SNS (Social Networking Services), Bonding and Bridging Social Capital. Computers \& Education, Vol. 75, pp. 263-273.

\title{
SOCIALINIU MEDIJU POVEIKIS JAUNIMO PILIETINIAM DALYVAVYMUI KINIJOJE
}

\author{
Jie Jiang, Algimants Kontauts
}

Latvijos universitetas (Latvija), PricewaterhouseCoopers (Latvija)

\section{Santrauka}

Šiame tyrime daugiausia dèmesio skiriama socialinėms medijoms Kinijoje, kaip jos veikia jaunimo pilietinị aktyvumą. Tyrimas nukreiptas ị Kinijos socialines medijas, kuriomis vis daugiau naudojamasi. 
Kinijoje pastebèta auganti socialinių medijų naudojimo tendencija, ypač WeChat, Weibo, QQ, Douyin ir Meitu. Tyrimo tikslas - ištirti, kaip šios socialinès medijos susijusios su pilietinio jaunimo dalyvavimu Kinijoje, konkrečiai, ar jos skatina jaunimo pilietinį dalyvavimą. Socialinių medijų naudojimas vertinamas, remiantis socialinių medijų paskyrų skaičiumi, šių paskyrų naudojimo trukme ir vidutinèmis laiko sąnaudomis socialinėse medijų paskyrose kas savaitę. Pilietinis dalyvavimas pasitelkus socialines žiniasklaidos priemo-

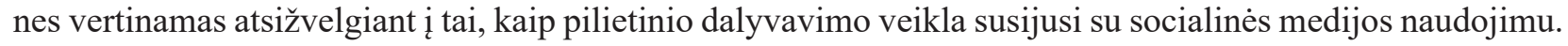

Dẻl kultūrinių ir istorinių priežasčių Kinijos jaunimo pilietinis dalyvavimas kol kas vis dar gana nauja tema. Žmonėms trūksta motyvacijos ir informacijos apie jų pilietines teises ir dalyvavimą pilietinèje veikloje. Todẻl atliekami tyrimai, kaip veiksmingiau skatinti jaunimo pilietinị dalyvavimą. Teoriškai socialinès medijos yra ịejimo neribojantis, plačiai naudojamas ir pigus būdas pateikti informaciją. Atlikta apklausa patvirtino prielaidą, kad socialinemis medijomis naudojamasi dalijantis informacija, kuri susijusi su viešaisiais reikalais ir dalyvavimu pilietinejje veikloje, rūpinimusi duomenų apsauga.

PAGRINDINIAI ŽODŽIAI: socialine medija, ,,WeChat“, jaunimas, pilietinis dalyvavimas, Kinija.

JEL KLASIFIKACIJA: J68, L86.

Received: 2018.12.12

Revised: 2018.12 .20

Accepted: 2019.01 .30 